\title{
Toxicity bioassay and sub-lethal effects of diazinon on blood profile and histology of liver, gills and kidney of catfish, Clarias gariepinus
}

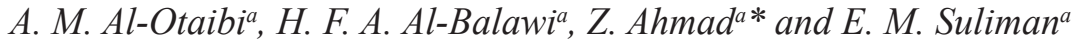 \\ aZoology Department, Science College, King Saud University, P. O. Box 2455, Riyadh 11451, Kingdom of Saudi Arabia \\ *e-mail: zahmed@ksu.edu.sa
}

Received: September 17, 2017 - Accepted: December 14, 2017 - Distributed: May 31, 2019

(With 7 figures)

\begin{abstract}
The catfish, Clarias gariepinus, was exposed to different acute concentrations (5-10 mg/l) of diazinon and the $\mathrm{Lc}_{50}$ value was recorded as high as $7.3 \mathrm{mg} / 1$ for 96 hours. The fishes exposed to three sub-lethal levels of diazinon $(0.73,1.095$ and $1.46 \mathrm{mg} / \mathrm{l})$ for 30 days showed that the pesticide induces changes in different blood parameters. Number of red blood cells (RBC), haemoglobin level and haematocrit values were elevated whereas white blood cells (WBC) count was reduced. Various blood indices like mean corpuscular volume (MCV), mean corpuscular haemoglobine $(\mathrm{MCH})$ and mean corpuscular haemoglobine concentration $(\mathrm{MCHC})$ vary insignificantly in the fish treated with diazinon. Glucose level and activity level of aspartate aminotransferase (AST) and alanine aminotransferase (ALT) was increased in Clarias gariepinus exposed to diazinon. Protein level in plasma of fish treated with pesticide was changed but the change was insignificant. Histological changes in the liver, gills and kidney of fishes exposed to diazinon were apparent when compared to control. Hepatocytes necrosis and bleeding were more distinct in the fishes exposed to pesticide. Glomerulus hypertrophy and bleeding in kidneys; and fusion and degeneration of secondary lamellae and epithelial hyperplasia in gills were also observed in the exposed fish.
\end{abstract}

Keywords: acute toxicity, histological changes, blood profile, diazinon, Clarias gariepinus.

\section{Toxicidade bioensaio e efeitos sub-letais do diazinon no perfil sangüíneo e histologia do fígado, brânquias e rim de peixe-gato, clarias gariepinus}

\section{Resumo}

O peixe-gato, Clarias gariepinus, foi exposto a diferentes concentrações agudas $(5-10 \mathrm{mg} / 1)$ de diazinon e o valor de Lc50 foi registrado tão alto quanto $7,3 \mathrm{mg} / 1$ por 96 horas. Os peixes expostos a três níveis sub-letais de diazinon $(0,73,1,095$ e 1,46 mg / 1) por 30 dias mostraram que o pesticida induz mudanças nos diferentes parâmetros sanguíneos. O número de glóbulos vermelhos, o nível de hemoglobina e os valores do hematócrito foram elevados, enquanto a contagem de leucócitos foi reduzida. Vários índices sanguíneos, como volume corpuscular médio (VCM), hemoglobina corpuscular média (HCM) e concentração de hemoglobina corpuscular média (CHCM) variam insignificantemente nos peixes tratados com diazinon. Nível de glicose e nível de atividade de AST e ALT foi aumentado em Clarias gariepinus expostos a diazinon. O nível de proteína no plasma de peixes tratados com pesticidas foi alterado, mas a mudança foi insignificante. Alterações histológicas no fígado, brânquias e rins de peixes expostos ao diazinon foram aparentes quando comparados ao controle. A necrose e o sangramento de hepatócitos foram mais distintos nos peixes expostos ao agrotóxico. Hipertrofia do glomérulo e sangramento nos rins; e fusão e degeneração de lamelas secundárias e hiperplasia epitelial em brânquias também foram observadas nos peixes expostos.

Palavras-chave: toxicidade aguda, alterações histológicas, perfil sangüíneo, diazinon, clarias gariepinus.

\section{Intruduction}

The toxic discharge from industries, different mining, and agricultural developments and processing find their way to the aquatic environment and may have detrimental effects on the inhabitants (Beijer K and Jornelo, 1979; Hamilton and Mehrle, 1986). Pesticides are one of the dangerous pollutants which cause great harm to the animals present in the aquatic environment including fishes. Diazinon with the chemical formula (0,0-diethyl 0-[6-methyl-2(1-methylethyl)4-pyrimidinyl] is an organophosphate insecticide and is extensively used in agriculture and domestic pest control. This pesticide is also used to control a variety of insects including: aphids, beetles, scales and pill bugs, primarily in household environment and in agriculture crops (Cong et al., 2009). Similar to other insecticides, the toxic effects of 
diazinon is also caused probably by affecting the activity of different enzymes (Fulton and Key, 2001; Oruç and Usta, 2007). The recent and notable work published on the effects of diazinon on various aspects of fish are those of Dutta and Meijer (2003); Aydin and Köprücü (2005); Lecoeur et al. (2006); Uner et al. 2006); Girón-Pérez et al. (2007); Adedeji et al. (2008); Bakhshwan et al. (2009); Inyang et al. (2010); Ahmad (2012); Soyingbe et al. (2012); Adebayo et al. (2013) and Ola-Davies et al. (2015).

It is imperative to find out the detrimental effects of pollutants specially pesticides on fish since they form an important link in food chain and their contamination by pesticides imbalance the aquatic system. Fish are an important source of protein and form a part of human food. Pesticides severely affect the fish in different ways mostly affecting the vital organs. The water-born pollutants primarily affects to the gills because they are the first organs to be exposed (Gallagher and Digiulio, 1992). Kidney plays a vital role in the maintenance of an organism's internal environment being the key to the regulation of volume of extracellular fluid and composition as well as acid-base balance. The toxic chemicals target to the kidney and disrupt its functions, and cause temporary or permanent derangement of homeostasis (Miller et al., 2002).

When the clinical diagnosis of fish physiology is used to examine the sub-chronic effects of pollutants, the blood profile of fish is measured (Wedemeyer and Yasutake, 1977). The physiological response of a fish to the contaminated environment are reflected through the haematological parameters like haemoglobin, haematocrit, blood cell counts, glycemia, and ion concentrations (Dethloff et al., 2001). The variation in the activity of glutamate oxaloacetate transminase (GOT) and Glutamate pyruvate transminase (GPT) also indicate the impacts of water pollution on fish (Bucher and Hofer, 1990). Clarias gariepinus is an economically important freshwater fish and its culture is considerably increasing in Saudi Arabia. In the present investigation an attempt was made to evaluate the acute toxicity of diazinon to catfish, Clarias gariepinus, measured by its mortality. The effects of sub-lethal concentration of diazinon was measured by registering the changes in haemoglobine concentration, cell counts, haematocrit values, glucose content and enzymes (AST and ALT) activities. The histological changes in the gills, liver and kidney caused by diazinon exposure were also studied.

\section{Materials and Methods}

Live and healthy specimens of catfish, Clarias gariepinus, were procured from a fish farm situated at Mozahmiah, west of Riyadh. The fish weight and length ranges from $32-68 \mathrm{~g}$ and $23-29 \mathrm{~cm}$, respectively. The fish specimens were kept in glass aquaria to get acclimatized to laboratory conditions for two weeks. The fish were fed a locally manufactured fish food to satiety twice daily during the period of acclimation. The aquarium water conditions like temperature, $\mathrm{pH}$, dissolved oxygen and hardness analyzed weekly were $23.5 \pm 1.5^{\circ} \mathrm{C}, 7.9 \pm 0.5,6.4 \pm 0.4 \mathrm{ppm}$ and $43.5 \pm 2.5 \mathrm{ppm}$ as $\mathrm{CaCO}_{3}$, respectively.

When the behaviors of fish give the impression that it is normal, showing the end of the acclimation time, ten fishes were kept in each aquarium filled with 30 litter of water. The known volume of stock solution of diazinon was added to different aquarium to obtain the test concentrations $(5,6,7,8,9$ and $10 \mathrm{mg} / \mathrm{l})$. A control set was also run with the same number of fish in same volume of water but without toxicant. Three sets of experimental and control group were run. The electrical air pumps were used to aerate the water of aquaria. During the period of exposure the feeding was stopped. The number of dead fish were registered and removed immediately from the water. Fresh concentration of diazinon was prepared daily. The method of Finney (1971) was used to find the $\mathrm{LC}_{50}$ value for 96 hours.

The other groups of fish were exposed to three different sub-lethal concentrations $(0.73,1.095$ and $1.46 \mathrm{mg} / 1$ which are $10 \%, 15 \%$ and $20 \%$ of the $\mathrm{LC}_{50}$ value) of diazinon for 30 days. A control set was also run for the same time but without diazinon. Three sets were run for both, experiment and control. The food was supplied twice daily to satiety. The fish from each aquarium of three replicates were removed at the end of experiment. The caudal peduncle of the fish excised and let the blood flow through dorsal aorta which was collected in heparinized vials. Blood of two or more fishes was pooled to have enough blood for the analysis of different parameters. The clotted blood samples were discarded. All the haematological and biochemical parameters were analyzed by well experienced technical professionals engaged in a vet nary technical laboratory at Riyadh, Saudi Arabia.

The liver, gills, and kidney were excised from the fishes which were sacrificed for the collection of blood. These organs were rinsed with physiological saline $(0.75 \% \mathrm{NaCl})$ to remove the mucus and blood attached to them. These tissues were then fixed for $24 \mathrm{~h}$ in SUSA. The standard methods were followed for sectioning and staining to these tissues. The steps followed for the preparation of slides were dehydration, clearing, and infiltration, embedding, sectioning and staining. The stain used for staining of the various tissues was haematoxylin.

The one way analysis of variance (ANOVA) was applied to test the significance of difference among the control and experimental values. The P values which were less than 0.5 considered statistically significant.

\section{Results and Discussion}

Mortality data are tabulated in Table 1 . The median lethal concentration $\left(\mathrm{LC}_{50}\right)$ of diazinon for 96 hours computed from the Figure 1 constructed using $\log _{10}$ concentrations of diazinon and probit of kill was $7.3 \mathrm{mg} / \mathrm{l}$. The $\mathrm{LC}_{50}$ value registered in the present investigation was more than the value recorded $\left(0.72 \times 10^{-4} \mathrm{ppm}\right)$ for the fry of Cyprinus carpio by Dembele et al. (2000). Girón-Pérez et al. (2007) reported the $\mathrm{LC}_{50}$ for Oreochromis niloticus as $7.83 \mathrm{mg} / \mathrm{l}$ which is very close to present value. The $96 \mathrm{~h} \mathrm{Lc}_{50}$ values of diazinon 
Table 1. Death of fish (in numbers) and percent mortality (in parentheses) in different concentrations of diazinon at different time intervals.

\begin{tabular}{ccccccc}
\hline $\begin{array}{c}\text { Concentration } \\
(\mathbf{m g} / \mathbf{l})\end{array}$ & $\begin{array}{c}\text { Concentration } \\
\left(\mathbf{L o g}_{\mathbf{1 0}}\right)\end{array}$ & $\mathbf{2 4}$ & $\mathbf{4 8}$ & $\mathbf{7 2}$ & $\mathbf{9 6}$ & Probit \\
\cline { 2 - 5 } Control & - & - & - & - & - & - \\
5.0 & 0.69897 & - & - & $2(10)$ & $3(15)$ & 3.9636 \\
6.0 & 0.77815 & - & $2(10)$ & $3(15)$ & $5(25)$ & 4.3255 \\
7.0 & 0.845098 & $2(10)$ & $3(15)$ & $5(25)$ & $9(45)$ & 4.8743 \\
8.0 & 0.90309 & $3(15)$ & $5(25)$ & $8(40)$ & $12(60)$ & 5.2533 \\
9.0 & 0.9542425 & $4(20)$ & $9(45)$ & $12(60)$ & $16(80)$ & 5.8416 \\
10.0 & 1.0000 & $6(30)$ & $10(50)$ & $18(90)$ & $20(100)$ & - \\
\hline
\end{tabular}

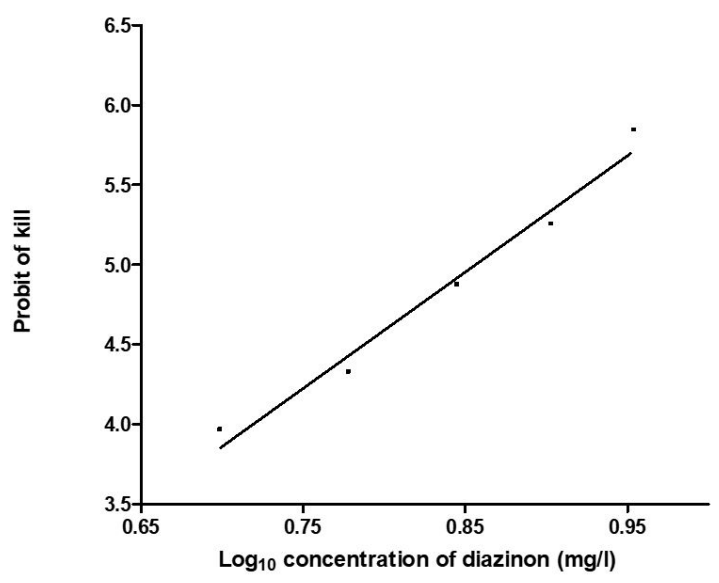

Figure 1. Relatioshipbetwen $\log _{10}$ concentration of diazinon and probit of kill.

was reported for fathead minnow (Pimephales minnow) as $7.8 \mathrm{mg} / \mathrm{l}$ and for sheephead minnow (Cyrinodon virginica) as $1.47 \mathrm{mg} / 1$ by Office of Pesticide Programs (2000). Keizer et al. (1991) have registered the $96 \mathrm{~h} \mathrm{LC}_{50}$ value of diazinon for Poecilia reticulate as $0.8 \mathrm{mg} / \mathrm{l}$ and for Brachydanio rerio as $8.0 \mathrm{mg} / 1$. The $\mathrm{LC}_{50}$ values of diazinon to different fish species for 96 hours were registered by Palacio et al. (2002) as 3.85 ppm (red tilapia), Koprucu et al. (2006) as $4.14 \mathrm{ppm}$ (European catfish), Machova et al. (2007) as 3ppm (guppy) and Adedeji et al. (2008) as $6.6 \mathrm{ppm}$ (Clarias gariepinus). The differences found in the toxic values of chemicals may be ascribed to the factors such as water hardness, $\mathrm{pH}$ and susceptibility of the test fish to pollutant. The discrepancy in the toxic level of diazinon to different species of fish mentioned above can be related to the disparities in susceptibility and tolerance linked to its accumulation, biotransformation and excretion. Neibor and Richardson (1980) opined that toxic potential of pesticides mainly depends upon the accumulation, the chemistry of compounds forming the pesticide and response of animals exposed to compound. Probably, the metabolic pathways of different fish species vary which result in varied patterns of bio-transformation, governing to produce more or less toxic metabolites (Jonsson and Toledo, 1993). The length and weight, corporal surface/body weight ratio and breathing rate (Singh and Narain, 1982 and Murty, 1986) are supposed to affects the toxic potential of pollutants. Varied level of inhibition of acetylcholinesterase, detoxification and absorption of pesticide are supposed to be the three main factors causing the selective toxicity of diazinon (Oh et al., 1991). The toxicity of pollutants depends generally on size and species of fish as well as duration of exposure (Oh et al., 1991 and Dutta et al., 1995).

Several abnormal behaviors like gulping of air, high opercular movement, erratic and agitated swimming, restlessness, burst swimming, hanging in the water column, fainting of dark brown color to light color were registered in the fish exposed to diazinon (Table 2). Similar to present observations were reported by Aguigwo (2002); Omoniyi et al. (2002); Rahman et al. (2002); Ayoola and Ajani (2008) and Ikele et al. (2011) in the fishes exposed to different pesticides.

Haematological parameters of fish are considered a suitable tool for evaluating the effects of pollutants (Roche and Boge, 1996). Cyriac et al. (1989) have reported the changes in several haematological parameters as indicators of metal exposure. The present results indicate that the sub-lethal exposure of diazinon to Clarias gariepinus has altered the blood parameters. The variations in blood profiles of the fish during period of pesticide exposure suggested that there are change in oxygen carrying capacity and osmotic disturbances in fish blood.

Data embodied in Table 3 indicated an increase in the red blood cell count, level of haemoglobin and values of haematocrit in the fish exposed to different doses of diazinon compared to control fish. The fish exposed to pesticide exhibit hyper activity probably to get out of the stressful medium and for this the fish would require more oxygen to fulfill the increased energy requirements. In other way treated fish secreted mucus in high quantities to coat the body especially gills to get relief from irritating effects of toxicant. Undoubtedly, this coating will reduce the gaseous exchange through gills. A hypoxic condition in fish is expected due to reduced supply and high demand of oxygen (Panday et al., 1979; Alkahem et al., 1998). As a compensatory mechanism the fish would synthesize more haemoglobin in older erythrocytes and release of 
Table 2. Study of five types of behavior of the African catfish under the influence of the chemical pesticide diazinon.

\begin{tabular}{ccccc}
\hline Behaviours & Control & $\mathbf{0 . 7 3} \mathbf{m g L}^{-1}$ & $\mathbf{1 . 0 9 5} \mathbf{~ m g L}^{-\mathbf{1}}$ & $\mathbf{1 . 4 6} \mathbf{~ m g L}^{-1}$ \\
\hline Surfacing & + & + & ++ & +++ \\
Threat & + & + & ++ & +++ \\
Movement of gills & + & + & ++ & +++ \\
Hanging in water column & + & + & ++ & +++ \\
\hline
\end{tabular}

Table 3. Biochemical and haematological changes in Clarias gariepinus exposed to diazinon. Values are mean of three replicates and \pm are the standard error.

\begin{tabular}{|c|c|c|c|c|c|}
\hline Parameters & Control & $0.73 \mathrm{mg} / \mathrm{l}$ & $1.095 \mathrm{mg} / \mathrm{l}$ & $1.46 \mathrm{mg} / \mathrm{l}$ & $\mathrm{P}<0.05$ \\
\hline $\begin{array}{c}\text { RBC } \\
\left(\text { Cellx } 10^{6} / \mu 1\right)\end{array}$ & $2.176 \pm 0.06$ & $2.200 \pm 0.057$ & $2.21 \pm 0.057$ & $2.53 \pm 0.052$ & $*$ \\
\hline $\begin{array}{c}\text { WBC } \\
\left(\text { Cellx } 10^{3} / \mu 1\right)\end{array}$ & $215.00 \pm 7.51$ & $216.2 \pm 6.58$ & $209.46 \pm 5.15$ & $208.63 \pm 7.59$ & \\
\hline $\begin{array}{l}\text { Haemoglobin } \\
\qquad(\mathrm{g} / \mathrm{dl})\end{array}$ & $10.90 \pm 0.29$ & $11.93 \pm 0.38$ & $11.07 \pm 0.44$ & $12.30 \pm 0.40$ & $*$ \\
\hline $\begin{array}{c}\text { Haematocrit } \\
(\%)\end{array}$ & $31.27 \pm 0.79$ & $33.10 \pm 1.00$ & $29.37 \pm 0.49$ & $35.13 \pm 0.93$ & $*$ \\
\hline $\begin{array}{c}\mathrm{MCH} \\
(\mathrm{Pg} / \text { cell })\end{array}$ & $50.20 \pm 2.33$ & $54.60 \pm 0.91$ & $50.05 \pm 0.99$ & $48.53 \pm 0.74$ & \\
\hline $\begin{array}{c}\mathrm{MCV} \\
\text { (fl/cell) }\end{array}$ & $143.89 \pm 0.82$ & $150.41 \pm 0.73$ & $133.14 \pm 5.35$ & $138.67 \pm 1.56$ & \\
\hline $\begin{array}{c}\mathrm{MCHC} \\
(\%)\end{array}$ & $34.92 \pm 1.47$ & $36.05 \pm 0.27$ & $37.72 \pm 1.76$ & $35.00 \pm 0.244$ & \\
\hline $\begin{array}{l}\text { Glucose } \\
(\mathrm{mg} / \mathrm{dl})\end{array}$ & $30.33 \pm 2.60$ & $51.83 \pm 3.94$ & $53.33 \pm 3.49$ & $64.83 \pm 2.46$ & * \\
\hline $\begin{array}{l}\text { Protein } \\
(\mathrm{mg} / \mathrm{dl})\end{array}$ & $5.17 \pm 0.44$ & $5.0 \pm 0.29$ & $5.67 \pm 0.60$ & $5.67 \pm 0.54$ & \\
\hline $\begin{array}{l}\text { ALT } \\
(\mathrm{U} / 1)\end{array}$ & $50.33 \pm 2.60$ & $55.47 \pm 2.84$ & $66.9 \pm 4.04$ & $89.87 \pm 3.43$ & $*$ \\
\hline $\begin{array}{l}\mathrm{AST} \\
(\mathrm{U} / \mathrm{l})\end{array}$ & $230.67 \pm 5.81$ & $233.0 \pm 6.93$ & $261.0 \pm 5.20$ & $278.67 \pm 5.21$ & $*$ \\
\hline
\end{tabular}

*Shows significant difference between treated and control values; RBC = Red Blood Cell; WBC = White Blood Cell; $\mathrm{MCH}=$ Mean Corpuscular Haemoglobin; $\mathrm{MCHC}=$ Mean Corpuscular Haemoglobin Concentration; ALT = Alanine Aminotransferase AST $=$ Aspartate Aminotransferase.

new cells in blood stream from the erythropoietic organs which improve the oxygen carrying capacity of blood (Murad and Mustafa, 1986; Al-Ghanim et al., 2008 and Al-Akel et al., 2010). Toxicant induce hyperactivity and impaired gill function due to the exposure of cadmium are supposed to be the reason for the increased haemoglobin level in fish (Majewski and Gilles, 1981).

Fall in the total leucocyte count was registered in the present investigation, and this might be due to malfunctioning of the haematopoietic system of diazinon exposed fish. Changes in the leucocyte system is apparent in the form of leucocytosis with heterophilia and lymphopenia in fish, this is the leucocytic response of animals under stress. Reduction in the leucocyte count in the fish exposed to trivalent chromium was registered (Alkahem, 1995), and attributed to sharp decline in the number of lymphocytes and thrombocytes. Decline in the count of lymphocytes in pesticide treated $O$. Niloticus was ascribed to fall in the delivery of these cells to the circulation due to the low production or alternatively an increased rate of elimination from the blood and subsequent rapid devastation of cells (Alkahem, 1995). Diminished leucocyte count in carp exposed to diazinon- based pesticide (Svoboda et al., 2001) and tilapia exposed to phosalone (Jaffer Ali and Rani, 2009) was registered.

The blood cell indices can cause reversible changes in the homeostatic system of fish. The values of erythrocyte count, haemoglobin level and packed cell volume affects the values of blood cell indices like $\mathrm{MCV}, \mathrm{MCH}$ and $\mathrm{MCHC}$. In the present study variations in the values of these indices was noticed in C. gariepinus after exposure of diazinon. A similar response was exhibited by common carp and other species of freshwater fishes exposed to acute toxic level of pesticides and lend support to present findings (Svoboda et al., 2001 and Rao, 2010).

The glucose level in the blood of exposed fish was significantly $(\mathrm{P}>0.05)$ elevated which may be due to the mobilization of glycogen in glucose. It is well established 
fact that fish secrete large quantities of glucocorticoids and catecholamines from adrenal tissue under stress condition. These hormones are well known to produce hyperglycemia in animals. The hyperglycemic condition registered in the fish exposed to diazinon may be ascribed to increased secretion of the hormones mentioned above which induce glycolysis in the liver and muscles of pesticide (diazinon) exposed fish.

AST (GOT) and ALT (GPT) enzymes are used to evaluate the toxic effects of pollutants (Nelson and Cox, 2000), hence are considered important diagnostic tools. The results of the present investigation show that the exposure of diazinon to Clarias gariepinus significantly $(\mathrm{P}<0.05)$ increase the activity of these enzymes. The activity of the enzymes AST and ALT was increased in the fish due to the exposure of metals (Al-Asgah et al., 2015). In the similar manner, Jeney et al. (1991) has registered an increased concentration of enzymes (SGOT, SGPT) in the serum of fish when treated with ammonia. According to them SGPT is very sensitive to the changes in the environment conditions. Significantly higher values of AST and ALT activities were presented by Mekkawy et al.
(2011) in the fish blood treated with cadmium. Increased activity of SGOT and SGPT in fish, C. punctatus, after the treatment of mercuric chloride (Sastry and Sharma, 1980) and monocrotophos (Agrahari et al., 2007) were also observed. Liver is rich in SGOT and SGPT as suggested by Vaglio and Landriscina (1999) and Palanivelu et al. (2005) and any damage to liver could lead to liberate large quantities of these enzymes into the blood. Modification in the activity of these enzymes in the fish due to the exposure of pollutants could be a sensitive indicator of cellular damage (Palanivelu et al., 2005 and Van Der Oost et al., 2003). The high activity values of these enzymes found in the fish treated with diazinon may be ascribed to damage caused to liver by the pesticide.

Histopathological observations made on gills, liver and kidneys of the diazinon exposed fish are represented in Figures 2.1 and 2.2, 3.1 and 3.2, 4.1 and 4.2, respectively. Fusion of secondary lamellae, epithelial lifting, epithelial hyperplasia and degeneration of secondary lamellae were observed in the gills of fish exposed to different level of diazinon. Magnitude of effects was more pronounced in the fish exposed to higher concentration and for longer

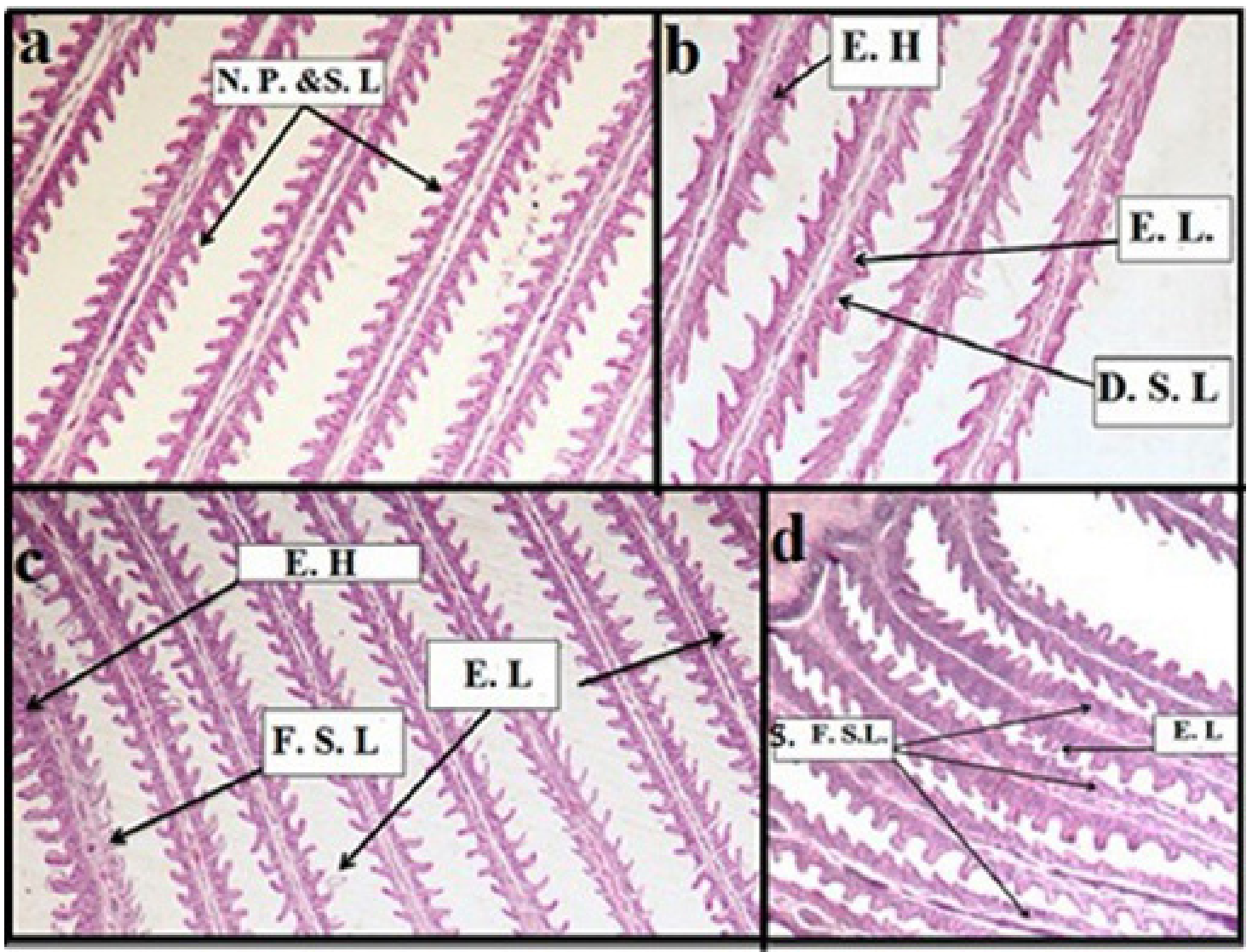

Figure 2.1. (H\&E stain 100X). Longitudinal section of $O$. niloticus gills exposed to different concentrations of Diazinon for 15 days: (a) control fish (exposed to $0.0 \mathrm{mgL}^{-1}$ ) showing normal primary (N.P.) and secondary lamellae (S.L). (b) Fish exposed to $0.73 \mathrm{mgL}^{-1}$ showing epithelial hyperplasia (E.H), epithelial lifting (E.L) and degeneration of secondary lamellae (D.S.L.). (c) Fish exposed to $1.095 \mathrm{mgL}^{-1}$ showing epithelial hyperplasia (E.H), Epithelial lifting (E.L), and fusion of secondary lamellae (F.S.L). (d) Fish exposed to $1.46 \mathrm{mgL}^{-1}$ showing epithelial lifting and severe fusion of secondary lamellae (S.F.S.L). 


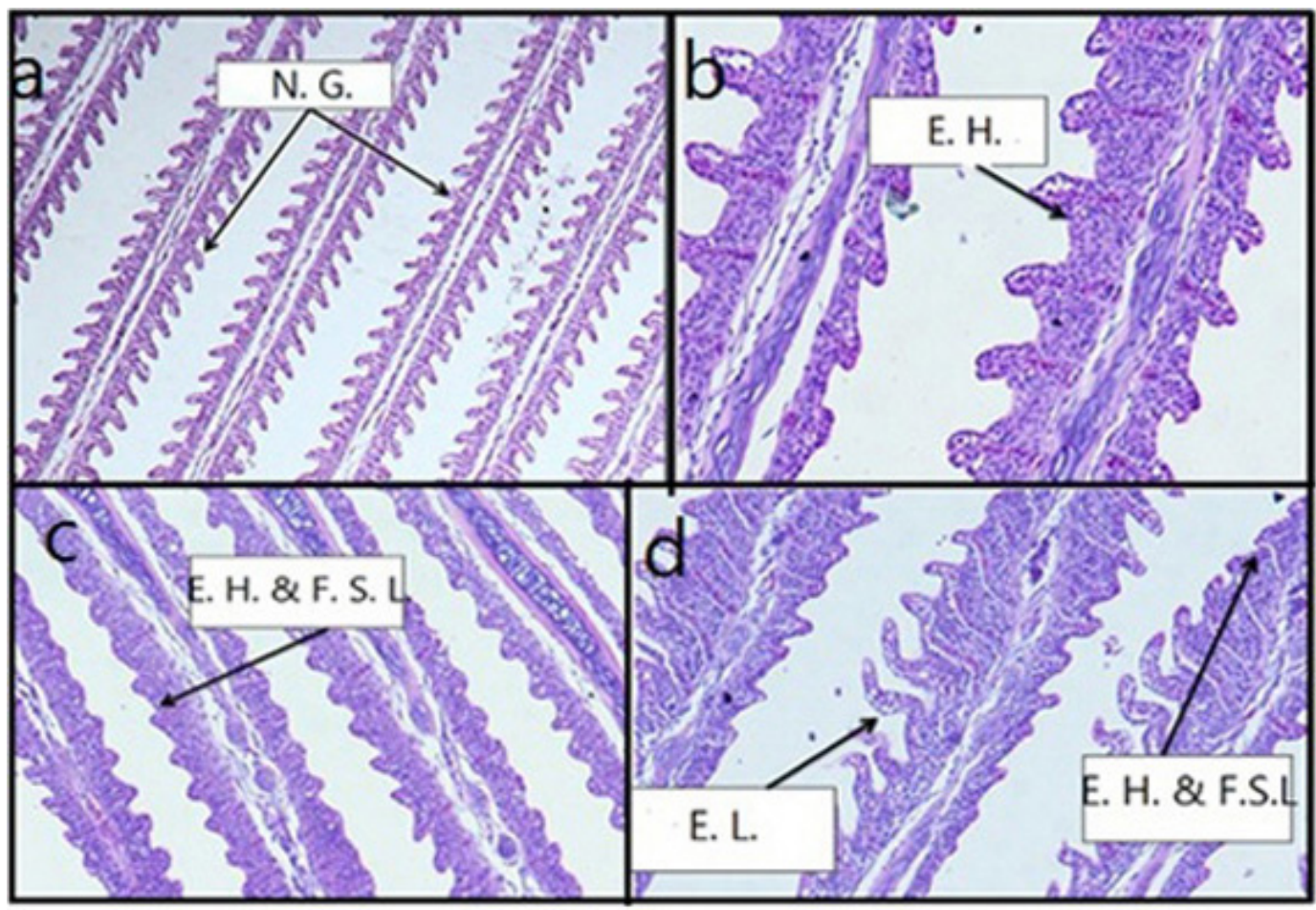

Figure 2.2. (H\&E stain 100X). Longitudinal section of O. niloticus gills exposed to different concentrations of Diazinon for 30 days (a) control fish (exposed to $0.0 \mathrm{mgL}^{-1}$ ) showing normal gill (N.G.) (b) exposed to $0.73 \mathrm{mgL}^{-1}$ showing epithelial hyperplasia (E.H). (c) Fish exposed to $1.095 \mathrm{mgL}^{-1}$ showing epithelial hyperplasia, and fusion of secondary lamellae (F.S.L). (d) Exposed to $1.46 \mathrm{mgL}^{-1}$ showing epithelial lifting, epithelial hyperplasia (E.H), and fusion of secondary lamellae (F.S.L).

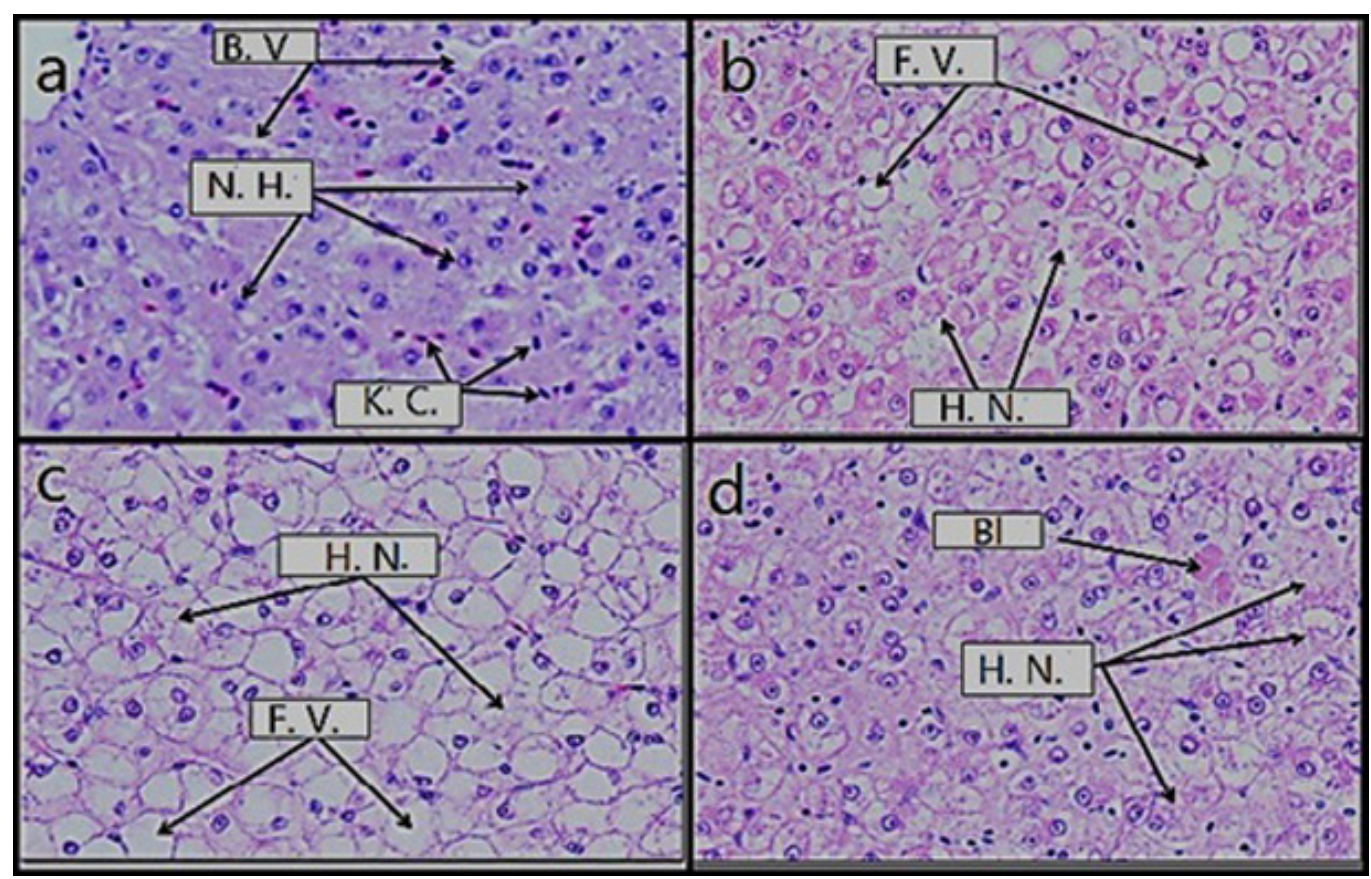

Figure 3.1. (H\&E stain 100X). Liver sections of O. niloticus exposed to different concentrations of diazinon for 15 days: (a) Control, exposed to $0.0 \mathrm{mgL}^{-1}$, showing normal liver with normal blood vessels (B.V), normal hepatocytes (N.H) and kupffer cells (K.C.). (b) Fish exposed to $0.73 \mathrm{mgL}^{-1}$ showing liver section with fat vacuoles (F.V.), and Hepatocytes necrosis (H.N.). (c) Fish exposed to $1.095 \mathrm{mgL}^{-1}$ showing hepatocyte necrosis (H.N.) and fat vacuoles (F.V.) and (d) Fish exposed to $1.46 \mathrm{mgL}^{-1}$ showing bleeding (Bl) and hepatocyte necrosis (H. N.). 


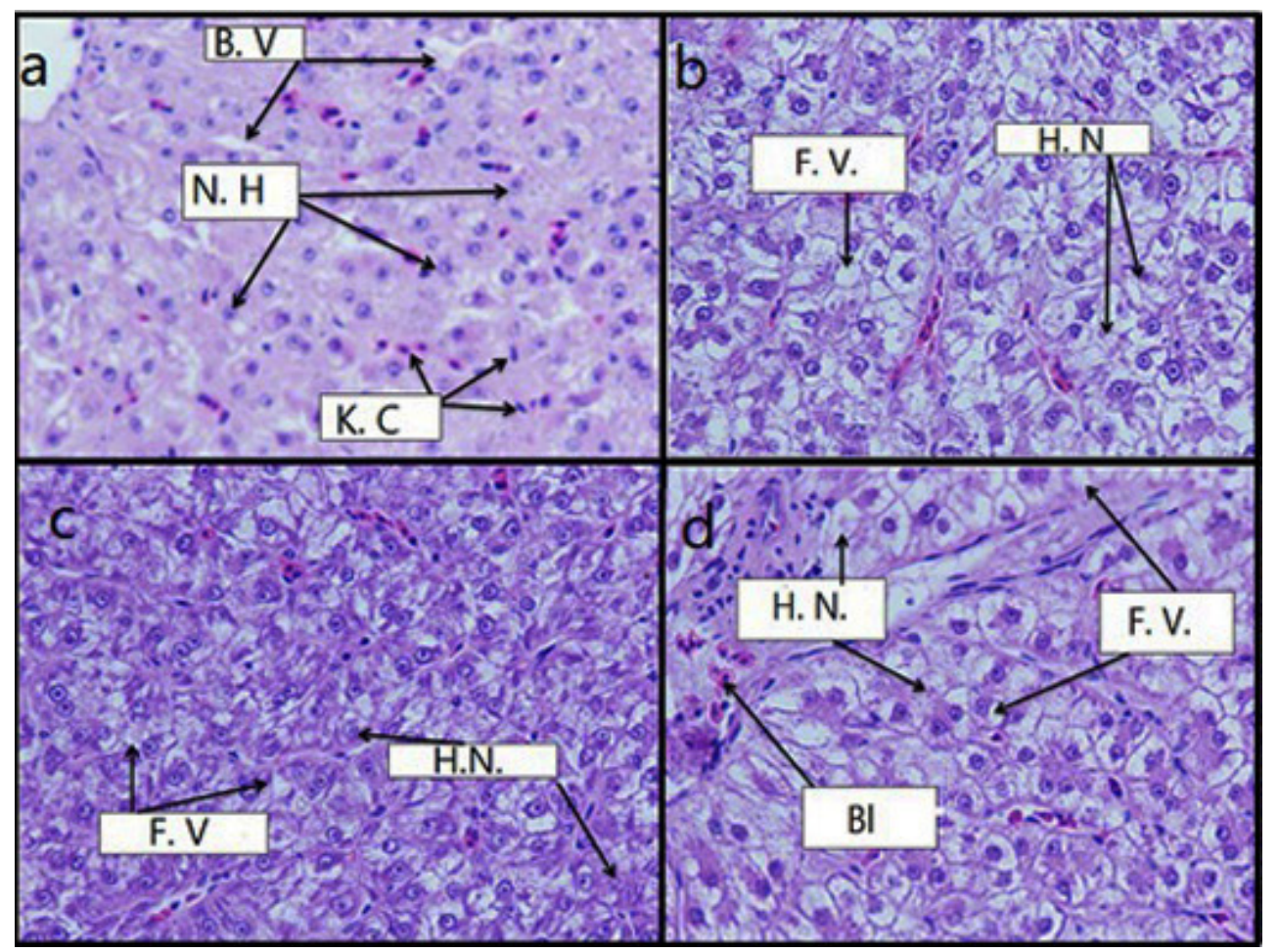

Figure 3.2. (H\&E stain 100X). Liver sections of O. niloticus exposed to different concentrations of diazinon for 30 days: (a) Control: exposed to $0.0 \mathrm{mgL}^{-1}$ showing normal liver with normal blood vessels (B.V), normal hepatocytes (N.H) and kupffer cells (K.C) (b) exposed to $0.73 \mathrm{mgL}^{-1}$ showing liver section with fat vacuoles and Hepatocytes necrosis (H.N). (c) exposed to $1.095 \mathrm{mgL}^{-1}$ showing hepatocyte necrosis (H.N) and fat vacuoles (F.V) and (d) exposed to $1.46 \mathrm{mgL}^{-1}$ showing hepatocyte necrosis (H. N), bleeding (Bl), and fat vacuoles (F.V).

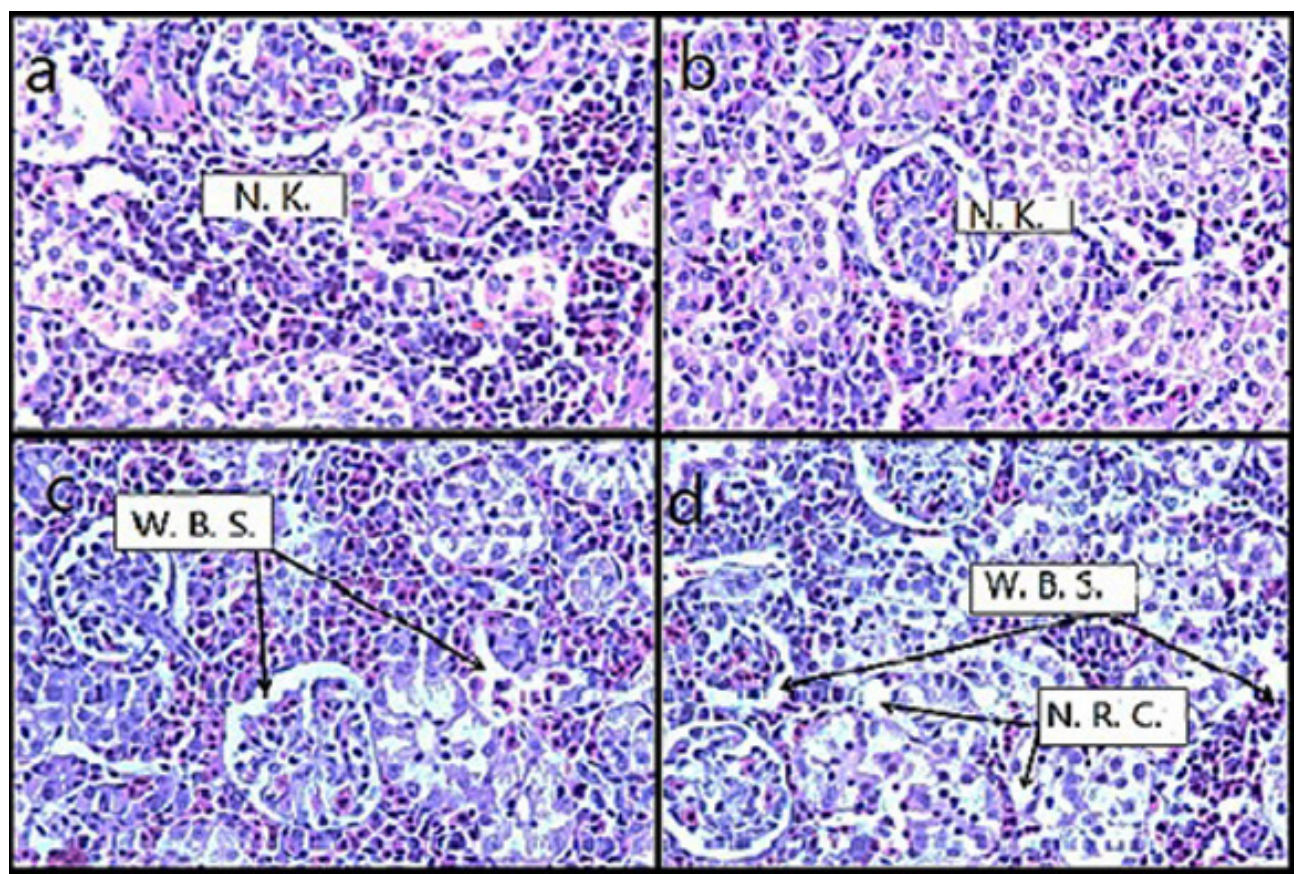

Figure 4.1. (H\&E stain 100X). Kidney sections of $O$. niloticus exposed to different concentrations of diazinon for 15 days: (a) Control: Fish exposed to $0.0 \mathrm{mgL}^{-1}$ showing normal kidney (N.K.). (b) Fish exposed to $0.73 \mathrm{mgL}^{-1}$ showing normal kidney (N.K.). (c) Fish exposed to $1.095 \mathrm{mgL}^{-1}$ showing normal wide bowman spacing (W.B.S.) and (d) exposed to $1.46 \mathrm{mgL}^{-1}$ showing normal wide bowman spacing (W.B.S.) and necrosis of renal cells (N.R.C.). 


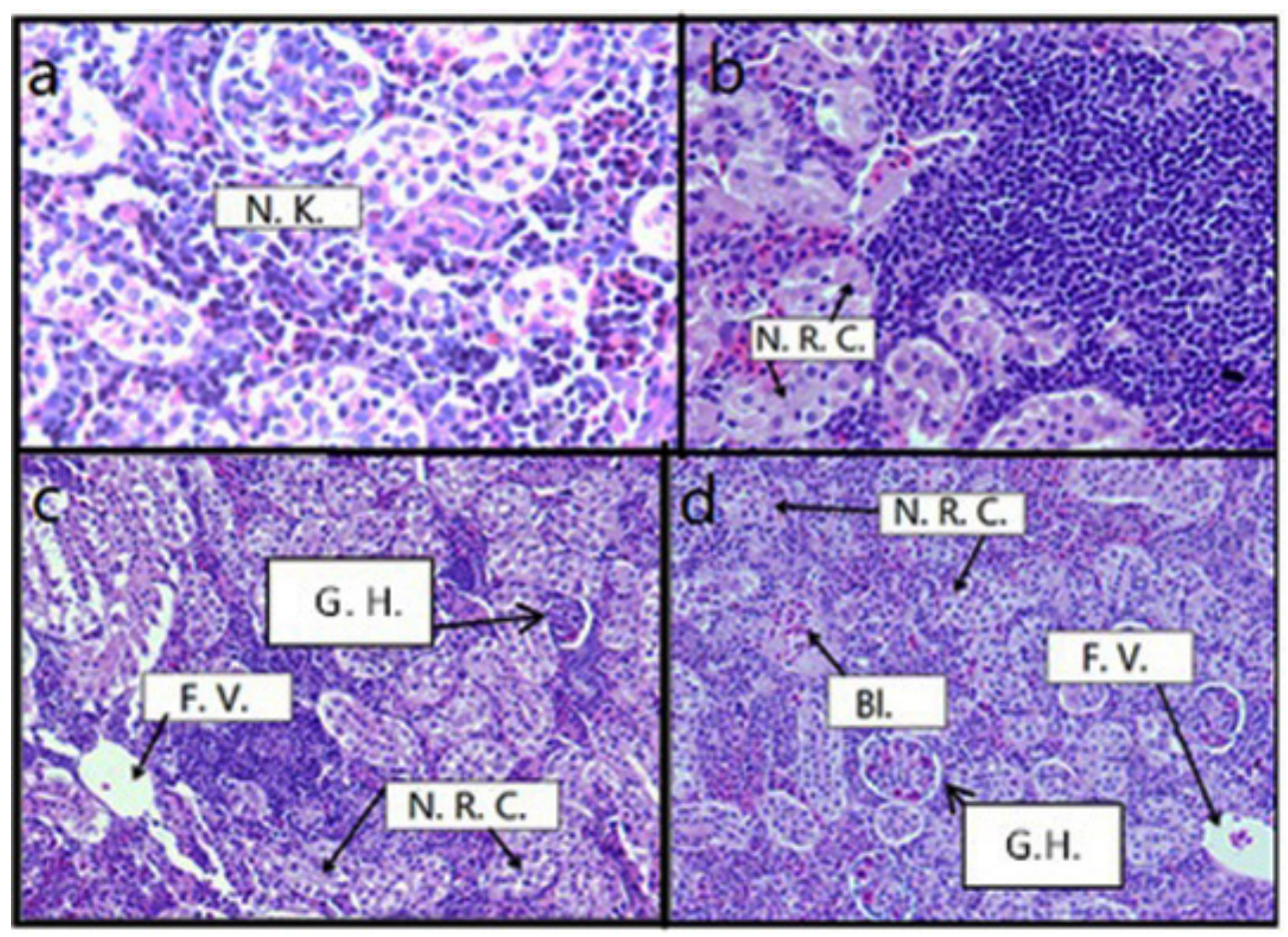

Figure 4.2. (H\&E stain 100X). Kidney sections of $O$. niloticus exposed to different concentrations of diazinon for 15 days: (a) Control: exposed to $0.0 \mathrm{mgL}^{-1}$ showing normal kidney (N.K.). (b) Fish exposed to $0.73 \mathrm{mgL}^{-1}$ showing necrosis of renal cells (N.R.C.). (c) Fish exposed to $1.095 \mathrm{mgL}^{-1}$ showing glomerular hypertrophy (G.H.), fat vacuoles (F.V.) and necrosis of renal cells (N.R.C).(d) exposed to $1.46 \mathrm{mgL}^{-1}$ showing necrosis of renal cells (N.R.C.), fat vacuoles (F.V.), bleeding (B1.) and glomerular hypertrophy (G.H.).

period of time (Figures 2.1 and 2.2). Gills are supposed to be the main respiratory organs and any damage to them would cause disturbance in all physiological and metabolic activities by curtailing the oxygen supply. It is quite apparent that the damage caused to the gills results in impairments in gaseous exchange capacity of the gills, which ultimately lead to respiratory distress. Similar view was presented by Rahman et al. (2002); Omitoyin et al. (2006) and Ezemonye and Ogbomida (2010) for the damage of gills in the fish treated with toxicants and support to present findings.

Normal hepatocytes and other cells were found in untreated fish (control). Changes like hepatocyte's hypertrophy, necrosis and vacuolization were found in the liver of fish treated with diazinon. Bleeding or hemorrhage were also seen the liver of fish exposed to high dose (Figures 3.1 and 3.2). Liver is an important organ for assessing the pollutant's effects as the chemicals are stored in it. Liver is also considered as major site for the biotransformation of chemicals, thus reduce their toxicity and make the excretion easy. Presence of fat vacuoles in the liver of treated fish showed evidence of fatty degeneration. Hepatocytes necrosis may be the results of inability of the fish to regenerate new hepatocytes (Ezemonye and Ogbomida, 2010). Necrosis occurred in the liver of exposed fish can also be related to the excessive burden of work for the detoxification of insecticide from the body. Similar line of reasoning for the liver necrosis was presented by Rahman et al. (2002) in fish treated with toxicant. Biagianti-Risbourg and Bastide (1995); Velmurugan et al. (2007) and Ikele et al. (2011) have reported necrosis of tubular epithelium and pyknotic nuclei in the liver of fish exposed to chemicals and support to our investigations.

Sections of the kidneys of fish exposed to diazinon showed minor histological changes after 15 days of treatment (Figure 4.1). After the prolongation of exposure (30 days) more severe effects, such as renal cell necrosis, bleeding and glomerulus hypertrophy were registered in the kidney (Figure 4.2). Ayoola and Ajani (2008) have also reported that exposure of cypermethrin causes pathological effects on gills, liver and kidneys of catfish. Fusion of tubules and condensation of glomeruli content were reported by them. Pyknotic nucleus, destruction of fusion of tubules, condensation of nuclei were observed in the kidney of Clarias gariepinus exposed to diethyl phthalate (Ikele et al., 2011). Ortiz et al. (2003) registered sloughing of the epithelium and necrosis in the walls of tubules due to the toxic effects of lindane.

\section{Conclusion}

The findings of this investigation indicate that the diazinon insecticide is moderately toxic to catfish, Clarias gariepinus, and even low doses of it could modify the biochemical and haematological profile of this fish. Exposure of diazinon to 
catfish significantly increased the activity of GOT and GPT. Blood sugar level was also elevated. Erythrocyte count, haemoglobin level and haematocrit values were high in the treated fish compared to control specimens. This shows how toxic is this chemical, hence, its use should be avoided and/ or stopped if possible.

\section{Acknowledgements}

The authors are thankful to the Deanship of Scientific Research, College of Science, King Saud University for providing financial support to this research project.

\section{References}

ADEBAYO, I.A., AKIN-OBASOLA, B.J. and BAJULAYE, O.M., 2013. Toxicological effect of diazinon on African catfish (Clarias anguillaris). IOSR Journal of Environmental Science. Toxicology and Food Technology, vol. 3, no. 1, pp. 64-71. http:// dx.doi.org/10.9790/2402-0316471.

ADEDEJI, O.B., ADEDEJI, A.O., ADEYEMO, O.K. and AGBEDE, S.A., 2008. Acute toxicity of diazinon to the African catfish Clarias gariepinus). African Journal of Biotechnology, vol. 7 , no. 5, pp. 651-654.

AGRAHARI, S., PANDEY, K.C. and GOPAL, K., 2007. Biochemical alteration induced by monocrophos in the blood plasma of fish, Channa punctatus (Bloch). Pesticide Biochemistry and Physiology, vol. 88, no. 3, pp. 268-272. http://dx.doi.org/10.1016/j. pestbp.2007.01.001.

AGUIGWO, J.N., 2002. The Toxic Effect of Cymbush Pesticide on growth and survival of African catfish, Clarias gariepinus (Burchell 182 2). Journal of Aquatic Sciences, vol. 17, no. 2, pp. 81-84. http://dx.doi.org/10.4314/jas.v17i2.19916.

AHMAD, Z., 2012. Toxicity bioassay and effects of sublethal exposure of malathion on biochemical composition and haematological parameters of Clarias gariepinus. African Journal of Biotechnology, vol. 11, pp. 8578-8585.

AL-AKEL, A.S., AL-BALAWI, H.F.A., AL-MISNED, F., MAHBOOB, S., AHMAD, Z. and SULIMAN, E.M., 2010. Effects of dietary copper exposure on accumulation, growth, and hematological parameters in Cyprinus carpio. Toxicological and Environmental Chemistry, vol. 92, no. 10, pp. 1865-1878. http:// dx.doi.org/10.1080/02772248.2010.486230.

AL-ASGAH, N.A., ABDEL-WARITH, A.W.A., YOUNIS, E.M. and ALLAM, H.Y., 2015. Haematological and biochemical parameters and tissue accumulatioons of cadmium in Oreochromis niloticus exposed to various concentrations of cadmium chloride. Saudi Journal of Biological Sciences, vol. 22, no. 5, pp. 543-550. http://dx.doi.org/10.1016/j.sjbs.2015.01.002. PMid:26288556.

AL-GHANIM, K.A., ALKAHEM-AL-BALAWI, H.F., ALAKEL, A.S., AL-MISNED, F., AHMAD, Z. and ANNAZRI, H., 2008. Ethological response and haematological and biochemical profile of carp (Cyrinus carpio) exposed to trichlorfon. Journal of Food Agriculture and Environment, vol. 6, pp. 473-479.

ALKAHEM, H.F., 1995. Behavioral responses and changes in some haematological parameters of the cichlid fish, Oreochromis niloticus, exposed to trivalent chromium. Magalat Game'at alMalik Abdul Aziz. Al-U'lum, vol. 7, no. 1, pp. 5-13. http://dx.doi. org/10.4197/Sci.7-1.1.
ALKAHEM, H.F., AHMAD, Z., AL-AKEL, A.S. and SHAMSI, M.J.K., 1998. Toxicity bioassay and changes in haematological parameters of Oreochromis niloticus induced by trichlorfon. Arab Gulf Journal of Scientific Research, vol. 16, pp. 581-593.

AYDIN, R. and KÖPRÜCÜ, K., 2005. Acute toxicity of diazinon on the common carp (Cyprinus carpio) embryos and larvae. Pesticide Biochemistry and Physiology, vol. 82, no. 3, pp. 220225. http://dx.doi.org/10.1016/j.pestbp.2005.03.001.

AYOOLA, S.O. and AJANI, E.K., 2008. Histopathological effects of cypermethrin on juvenile African catfish (Clarias gariepinus). World Journal of Biological Research, vol. 1, pp. 1-14.

BAKHSHWAN, S., HAMED, H., MARZOUK, M. and HANNA, M., 2009. Some investigations on the clinical and biochemical alterations associated with dizinon toxicity in Clarias gariepinus. Egyptian Journal of Aquatic Biology and Fisheries, vol. 13, no. 2, pp. 173-197. http://dx.doi.org/10.21608/ejabf.2009.2039.

BEIJER, K. and JORNELO, A., 1979. Sources, transport and transformation of metals in the environment. In: L. Friberg, G.R. Nordberg and V.B. Vouks, eds. Handbook on the toxicology of metals. New York: Elsevier, North Holland Biomedical Press, pp. 47-63.

BIAGIANTI-RISBOURG, S. and BASTIDE, J., 1995. Hepatic perturbation induced by a herbicide (atrazine) in Juvenile grey mullet Liza ramada (Mugilidae, Teleotei): An ultrastructural study. Aquatic Toxicology (Amsterdam, Netherlands), vol. 31, no. 3, pp. 217-229. http://dx.doi.org/10.1016/0166-445X(94)00065-X.

BUCHER, F. and HOFER, R., 1990. Effect of domestic wastewater on serum enzyme activities of brown trout (Salmo truta). Comparative Biochemistry and Physiology, vol. 97, pp. 385-390.

CONG, N.V., PHUONG, N.T. and BAYLEY, M., 2009. Effects of repeated exposure of diazinon on cholinesterase activity and growth in snakehead fish (Channa striatus). Ecotoxicology and Environmental Safety, vol. 72, no. 3, pp. 699-703. http://dx.doi. org/10.1016/j.ecoenv.2008.10.007. PMid:19054558.

CYRIAC, P.J., ANTONY, A. and NAMBISAN, P.N., 1989. Hemoglobin and hematocrit values in the fish Oreochromis mossambicus (Peters) after short term exposure to copper and mercury. Bulletin of Environmental Contamination and Toxicology, vol. 43, no. 2, pp. 315-320. http://dx.doi.org/10.1007/BF01701764. PMid:2775899.

DEMBÉle, K., HAUBRUGe, E. and GASPAR, C., 2000. Concentration effects of selected insecticides on brain acetylcholinesterase in the common carp (Cyrinus carpio L.). Ecotoxicology and Environmental Safety, vol. 45, no. 1, pp. 4954. http://dx.doi.org/10.1006/eesa.1999.1829. PMid:10677267.

DETHLOFF, G.M., BAILEY, H.C. and MAIER, K.J., 2001. Effect of dissolved copper on selected haematological, biochemical and immunological parameters of wild rainbow trout (Oncorhynchus mykiss). Archives of Environmental Contamination and Toxicology, vol. 40, no. 3, pp. 371-380. http://dx.doi.org/10.1007/s002440010185. PMid: 11443368

DUTTA, H.M. and MEIJER, H.J.M., 2003. Sublethal effects of diazinon on the structure of the testis of bluegill, Lepomis macrochirus: a microscopic analysis. Environmental Pollution, vol. 125 , no. 3, pp. 355-360. http://dx.doi.org/10.1016/S02697491(03)00123-4. PMid:12826413.

DUTTA, H.M., MUNSHI, J.S.D., DUTTA, G.R., SINGH, N.K., ADHIKARI, S. and RICHMONDS, C.R., 1995. Age related differences in the inhibition of brain acetylcholinesterase activity 
of Heteropneustes fossilis (Bloch) by malathion. Comparative Biochemistry and Physiology, vol. 111, no. 2, pp. 331-334. http:// dx.doi.org/10.1016/0300-9629(94)00166-Q.

EZEMONYE, L. and OGBOMIDA, T.E., 2010. Histopathological effects of Gammalin 20 on African catfish (Clarias gariepinus). Applied Environmental and Soil Science, vol. 2010, 138019. http://dx.doi.org/10.1155/2010/138019.

FINNEY, D.J., 1971. Probit analysis. Delhi: S. Chand and Company Ltd. Ram Nagar.

FULTON, M.H. and KEY, P.B., 2001. Acetylcholinesterase inhibition in estuarine fish and invertebrates as an indicator of organophosphorus insecticide exposure and effects. Environmental Toxicology and Chemistry, vol. 20, no. 1, pp. 37-45. http://dx.doi. org/10.1002/etc.5620200104. PMid:11351414.

GALLAGHER, E.P. and DIGIULIO, R.T., 1992. A comparison of glutathione-dependent enzymes in liver, gills and posterior kidney of channel catfish (Ictalurus punctatus). Comparative Biochemistry and Physiology, vol. 102, no. 3, pp. 543-547. PMid:1360360.

GIRÓN-PÉREZ, M.I., SANTERRE, A., GONZALEZ-JAIME, F., CASAS-SOLIS, J., HERNÁNDEZ-CORONADO, M., PEREGRINA-SANDOVAL, J., TAKEMURA, A. and ZAITSEVA, G., 2007. Immunotoxicity and hepatic function evaluation in Nile tilapia (Oreochromis niloticus) exposed to diazinon. Fish \& Shellfish Immunology, vol. 23, no. 4, pp. 760-769. http://dx.doi. org/10.1016/j.fsi.2007.02.004. PMid:17478099.

HAMILTON, S.J. and MEHRLE, P.M., 1986. Metallothionein in fish: review of its importance in assessing stress from metal contaminants. Transactions of the American Fisheries Society, vol. 115 , no. 4, pp. 596-609. http://dx.doi.org/10.1577/15488659(1986)115<596:MIF>2.0.CO;2.

IKELE, C.B., MGBENKA, B.O. and OLUAH, N.S., 2011. Histopathological effects of diethyl phthalate on Clarias gariepinus juveniles. Animal Research International, vol. 8, no. 3, pp. 1431-1438.

INYANG, I.R., DAKA, E.R. and OGAMBA, E.N., 2010. Effects of sub-lethal concentrations of diazinon on total protein and transaminase activities in Clarias gariepinus. Current Research Journal of Biological Sciences, vol. 2, no. 6, pp. 390-395.

JAFFER ALI, H.A. and RANI, V.J., 2009. Effect of phosalone on haematological indices in the tilapia, Oreochromis mossambicus. Turkish Journal of Veterinary and Animal Sciences, vol. 33, pp. 407-411.

JENEY, G., NEMCSOK, J., JENEY, Z.S. and OLAH, J., 1991. Acute effect of sublethal ammonia concentrations on common carp (Cyprinus carpio L.). II. Effect of ammonia on blood plasma transminases (GOT, GPT), GDH enzyme activity and ATP value. Aquaculture (Amsterdam, Netherlands), vol. 104, no. 1-2, pp. 149-156. http://dx.doi.org/10.1016/0044-8486(92)90145-B.

JONSSON, C.M. and TOLEDO, M.C.F., 1993. Acute toxicity of endosulfan to the fish Hyphessobrycon bifasciatus and Brachydanio rerio. Archives of Environmental Contamination and Toxicology, vol. 24, no. 2, pp. 151-155. http://dx.doi.org/10.1007/BF01141341.

KEIZER, J., D'AGOSTINO, G. and VITTOZZI, L., 1991. The importance of biotransformation in the toxicity of xenobiotics to fish. 1: Toxicity and bioaccumulation of diazinon in guppy (Poecillia reticulata) and zebra fish (Brachydanio rerio). Aquatic Toxicology (Amsterdam, Netherlands), vol. 21, no. 3-4, pp. 239254. http://dx.doi.org/10.1016/0166-445X(91)90075-K.
KOPRUCU, S.S., KOPRUCU, K., URAL, M.S., ISPIR, U. and PALA, M., 2006. Acute toxicity of organophosphorous pesticide diazinon and its effects on behaviour and some hematological parameters of fingerling European catfish (Silurus glanis L). Pesticide Biochemistry and Physiology, vol. 86, no. 2, pp. 99-105. http://dx.doi.org/10.1016/j.pestbp.2006.02.001.

LECOEUR, S., VIDEMANN, B. and MAZALLON, M., 2006. Effect of organophosphate pesticide diazinon on expression and activity of intestinal $P$ - glycoprotein. Toxicology Letters, vol. 161, no. 3, pp. 200-209. http://dx.doi.org/10.1016/j.toxlet.2005.09.003. PMid:16221533.

MACHOVA, J., PROKES, M., SVOBODOVA, Z., ZLABEK, V., PENAZ, M. and BARUS, V., 2007. Toxicity of diazinon 60 EC for Cyprinus carpio and Poecilia reticulata. Aquaculture International, vol. 15, no. 3-4, pp. 267-276. http://dx.doi. org/10.1007/s10499-007-9078-1.

MAJEWSKI, H.S. and GILLES, M.A., 1981. Cardiovascularrespiratory responses of rainbow trout (salmo gairdneri) during chronic exposure to sub-lethal concentrations of cadmium. Water Research, vol. 15, no. 10, pp. 1211-1217. http://dx.doi. org/10.1016/0043-1354(81)90096-8.

MEKKAWY, I.A.A., MAHMOUD, U.M., WASSIF, E.T. and NAGUIB, M., 2011. Effects of cadmium on some haematological and biochemical characteristics of Oreochromis niloticus (Linnaeus 1758) dietary supplemented with tomato paste and vitamin E. Fish Physiology and Biochemistry, vol. 37, no. 1, pp. 71-84. http://dx.doi.org/10.1007/s10695-010-9418-3. PMid:20625929.

MILLER, G.G., SWEET, L.I., ADAMS, J.V., OMANN, G.M., PASSINO-READER, D.R. and MEIER, P.G., 2002. Invitro toxicity and interactions of environmental contaminants (Arochlor 1254 and mercury) and immunomodulatory agents (lipopolysaccharide and cortisol) on thymocytes from lake trout (Salvelinus namaycush). Fish \& Shellfish Immunology, vol. 13, no. 1, pp. 11-26. http:// dx.doi.org/10.1006/fsim.2001.0381. PMid:12201650.

MURAD, A. and MUSTAFA, S., 1986. Ethological and haematological response of catfish, Heteropneustes fossils, exposed to exogenous urea. Japanese Journal of Ichthyology, vol. 36 , pp. $75-81$.

MURTY, A.S., 1986. Toxicity of pesticides to fish. Boca Raton: CRC Press Inc. 143 pp.

NEIBOR, E. and RICHARDSON, D.H., 1980. Replacement of non-descript term heavy metal by a biological and chemically significant classification of metal lens. vol. 3. Environmental Pollution Series, no. 1.

NELSON, D.L. and COX, M.M., 2000. Lehninger principles of biochemistry. New York: Worth Publishers. pp. 623-658.

OFFICE OF PESTICIDE PROGRAMS, 2000. Pesticide ecotoxicity database (formerly: environmental effects database). Washington: Environmental Fate and Effects Division, US EPA.

OH, H.S., LEE, S.K., KIM, Y.H. and ROH, J.K., 1991. Mechanism of selective toxicity of diazinon to killifish (Oryzias latipes) and loach (Misgurnus anguillicaudatus). Aquatic Toxicology and Risk Assessment, vol. 14, pp. 343-353.

OLA-DAVIES, O.E., FAGBOHUN, A.F., EMIKPE, B.O. and ADEYEMO, O.K., 2015. Diazinon-induced clastogenity and pathological changes in ovaries and testes of Clarias gariepinus. Agricultural Science, vol. 6, no. 01, pp. 146-151. http://dx.doi. org/10.4236/as.2015.61012. 
OMITOYIN, B.O., AJANI, E.K., ADESINA, B.T. and OKUAGU, C.N.F., 2006. Toxicity of Lindane (Gamma Hexachloro-CycloHexane) to Clarias gariepinus (Burchell 1822). World Journal of Zoology, vol. 1 , no. 1 , pp. 57-63.

OMONIYI, I., AGBON, A.O. and SODUNKE, S.A., 2002. Effect of lethal and Sub lethal concentration of tobacco (Nicotiana tobaccum) leaf dust extract on weight and haematological changes in Clarias gariepinus (Burchell). Journal of Applied Science \& Environmental Management, vol. 6, no. 2, pp. 37-41. http://dx.doi. org/10.4314/jasem.v6i2.17174

ORTIZ, J.B., GONZÁLEZ DE CANALES, M.L. and SARASQUETE, C., 2003. Histopathological changes induced by lindane $(\gamma-\mathrm{HCH})$ in various organs of fishes. Scientia Marina, vol. 67, no. 1, pp. 53-61. http://dx.doi.org/10.3989/scimar.2003.67n153.

ORUÇ, E.Ö. and USTA, D., 2007. Evaluation of oxidative stress responses and neurotoxicity potential of diazinon in different tissues of Cyprinus carpio. Environmental Toxicology and Pharmacology, vol. 23, no. 1, pp. 48-55. http://dx.doi.org/10.1016/j. etap.2006.06.005. PMid:21783736.

PALACIO, J.A., HENAO, B., VÉLEZ, J.H., GONZÁLEZ, J. and PARRA, C.M., 2002. Acute toxicity and bioaccumulation of pesticide diazinon in red tilapia Oreochromis niloticus x Mossambicus albino. Environmental Toxicology, vol. 17, no. 4, pp. 334-340. http://dx.doi.org/10.1002/tox.10063. PMid:12203954.

PALANIVELU, V., VIJAYAVEL, K., BALASUBRAMANIAN, S.E. and BALASUBRAMANIAN, M.P., 2005. Influence of insecticidal derivative (cartap hydrochloride) from the marine polycheate on certain enzyme systems of the fresh water fish Oreochromis mossambicus. Journal of Environmental Biology, vol. 26, no. 2, pp. 191-195. PMid:16161972.

PANDAY, N.B., CHANCHAL, A.K., SINGH, S.B., PRASAD, S. and SINGH, M.P., 1979. Effect of some biocides on the blood and oxygen consumptiom of Channa punctatus (Bloch). In: Proceedings of the Symposium on Environmental Biology; 1978; Muzaffarnagar, India. Muzaffarnagar: Academy of Environmental Biologypp, pp. 343-348.

RAHMAN, M.Z., HOSSAIN, Z., MELLAH, M.F.R. and AHMED, G.U., 2002. Effect of Diazinon 60EC on Anabus testudinus, Channa punctatus and Barbades gomonotus. Naga. The Iclarm Quarterly, vol. 25, pp. 8-11.

RAO, D.S., 2010. Carbaryl induced changes in the haematological, serum biochemical and immunological responses of common carp Cyprinus carpio (L.) with special emphasis on herbal extracts as immunomodulators. India: Andhra university, 235 p. Ph. D. Thesis.

ROCHE, H. and BOGE, G., 1996. Fish blood parameters as a potential tool for identification of stress caused by environmental factors and chemical intoxication. Marine Environmental
Research, vol. 41, no. 1, pp. 27-43. http://dx.doi.org/10.1016/01411136(95)00015-1.

SASTRY, K.V. and SHARMA, K., 1980. Diazinon effect on the activities of brain enzymes from Ophiocephalus (Channa) punctatus. Bulletin of Environmental Contamination and Toxicology, vol. 24, no. 1, pp. 326-332. http://dx.doi.org/10.1007/BF01608117.

SINGH, B.B. and NARAIN, A.S., 1982. Acute toxicity of Thiodan to catfish (Heteropneustes fossilis). Bulletin of Environmental Contamination and Toxicology, vol. 28, no. 1, pp. 122-127. http:// dx.doi.org/10.1007/BF01608424. PMid:7066541.

SOYINGBE, A.A., OGUNYANWO, O.O., HAMMED, T.B. and ADESOPE, A.O., 2012. Effects of sublethal concentrations of diazinon on total protein in tilapia fish (Oreochromis Niloticus). IOSR Journal of Environmental Science. Toxicology and Food Technology, vol. 1, no. 1, pp. 22-25. http://dx.doi.org/10.9790/24020112225

SVOBODA, M., LUSKOVÁ, V., DRASTICHOVÁ, J. and ŽLÁBEK, V., 2001. The effect of diazinon on haematological indices of common carp (Cyprinus carpio L.). Acta Veterinaria Brno, vol. 70, no. 4, pp. 457-465. http://dx.doi.org/10.2754/ avb200170040457.

UNER, N., ORUÇ, E.Ö., SEVGILER, Y., SAHIN, N., DURMAZ, H. and USTA, D., 2006. Effects of diazinon on acetylcholinesterase activity and lipid peroxidation in the brain of Oreochromis niloticus. Environmental Toxicology and Pharmacology, vol. 21, no. 3, pp. 241-245. http://dx.doi.org/10.1016/j.etap.2005.08.007. PMid:21783664.

VAGLIO, A. and LANDRISCINA, C., 1999. Changes in liver enzyme activity in the teleost, Sparus auratus in response to cadmium intoxication. Ecotoxicology and Environmental Safety, vol. 43, no. 1, pp. 111-116. http://dx.doi.org/10.1006/ eesa.1999.1778. PMid:10330329.

VAN DER OOST, R., BEYER, J. and VERMEULEN, N.P., 2003. Fish bioaccumulation and biomarkers in environmental risk assessment, a review. Environmental Toxicology and Pharmacology, vol. 13, no. 2, pp. 57-149. http://dx.doi.org/10.1016/S13826689(02)00126-6. PMid:21782649.

VELMURUGAN, B., SELVANAYAGAM, M., CENGIZ, E.I. and UNLU, E., 2007. Effect of fenvalerate on different tissues of freshwater fish Cirrhinus mrigala. Journal of Environmental Science and Health., vol. 42, no. 2, pp. 157-163. http://dx.doi. org/10.1080/03601230601123292. PMid:17365330.

WEDEMEYER, G.A. and YASUTAKE, W.T., 1977. Clinical methods for the assessment of the effects of environmental stress on the fish health. United States Technical Papers and United States Fish Wildlife Services, vol. 89, pp. 1-18. 